\title{
Corruption and Tax Noncompliance Variables: An Empirical Investigation From Yemen
}

\author{
Mohammed Mahdi Obaid ${ }^{1,2}$ \& Noraza Mat Udin ${ }^{1}$ \\ ${ }^{1}$ Tunku Puteri Intan Safinaz School of Accountancy, Universiti Utara Malaysia, Kedah, Malaysia \\ ${ }^{2}$ Department of Accounting, Faculty of Administrative Sciences, Seiyun University, Hadhramout, Yemen \\ Correspondence: Mohammed Mahdi Obaid, Department of Accounting, Faculty of Administrative Sciences, Seiyun \\ University, Hadhramout, Yemen.
}

Received: March 3, 2020

doi:10.5430/ijfr.v11n4p52
Accepted: April 15, 2020

Online Published: June 28, 2020

URL: https://doi.org/10.5430/ijfr.v11n4p52

\begin{abstract}
Tax revenue is an important source of income for various governments around the world. However, challenges, as a result of corruption and tax noncompliance behaviour among the taxpayers, are hindering the adequate generation of such revenues for the government. The objective of this study is to investigate the effect of corruption and other tax noncompliance variables on tax revenue generation in Yemen. The study used survey research design via a questionnaire to collect data from 264 individual taxpayers in the Hadhramout Governorate. The collected data was analyzed using SPSS to perform reliability test, descriptive statistics, multicollinearity test, and regression analysis. The findings of the study show that corruption and tax rate are positively related to tax noncompliance; income level is negatively related to tax noncompliance; whereas penalty rate and education level are positive but not related to tax noncompliance. The implication of the study is that the government and the tax authority should update and institute new tax laws and policies that could minimize corruption among their officials and create more awareness among the taxpayers on the importance of paying tax to the government, so as to increase their compliance behaviour.
\end{abstract}

Keywords: corruption, tax noncompliance, tax revenue, individual, Yemen

\section{Introduction}

Taxes are regarded as a primary source of revenue, which is a crucial instrument for funding most government expenditure around the globe. Unfortunately, tax noncompliance among the individual taxpayers has become a persistent problem that is hindering many governments from generating sufficient revenue, thus adversely affecting the financing of public activities (Kirchler, 2007; Khan \& Ahmad, 2014; COCA, 2018; IMF, 2016; MPIC, 2018; Obaid, Ibrahim, \& Mat-Udin, 2020b). Tax non-compliance is considered as a global menace and a crucial phenomenon that affects the developed as well as developing economies (Hindriks, Peralta, \& Weber, 2008). At the international level, the issue of tax noncompliance has drawn the attention of researchers, such as Allingham and Sandmo (1972); James and Alley (2002); McGee and Lingle (2006); and Kirchler (2007), to study the factors that are related to the phenomenon. However, the problem continues to undermine the efforts of revenue authorities and many governments, especially from the developing nations, such as Yemen (Obaid, Ibrahim, \& Mat-Udin, 2020a; Al-Ttaffi., 2017).

In Yemen, the tax authority has undergone several reforms and enacted various tax laws to minimize the weaknesses in the tax system and to enhance revenue generation by way of increasing tax compliance. Tax revenues are regarded as an essential means by which Yemen derives its national income after oil money. About $23.9 \%$ of the government's budget is financed by tax revenues (Al-Faseel, 2014). However, tax noncompliance remains a major problem and an issue of concern to the Yemeni tax authority, in particular, and the government, in general (Al-Ttaffi \& Abdul-Jabbar, 2016; Al-Sharabi \& Al-Slehi, 2015; Al-Saadi, 2014; Obaid et al., 2020b). For instance, the estimated amount of tax noncompliance in 2012, 2013, and 2014 was reported to have reached $\$ 2.5$ billion, $\$ 3$ billion, and $\$ 4$ billion, respectively (Central Organization of Audit \& Control [COAC], 2012; Al-Saadi, 2014; COCA, 2014; Al-Sharabi \& Al-Slehi, 2015; Al-Ttaffi \& Abdul-Jabbar, 2016; World Bank, 2018; Index Mundi, 2019; Obaid et al., 2020b).

There is no doubt that this kind of attitude and behaviour of Yemeni taxpayers is very worrisome to the tax authority 
in generating adequate revenues for the government. This, in turn, has affected government functions, especially in the provision of infrastructure projects and looking after the social well-being of the citizens. Several factors have been identified as the reasons why Yemeni individuals are involved in tax noncompliance behaviour. Indeed, corruption among the government and tax officials has been identified as one of the major reasons which has led to the problems of poor infrastructure and lack of development in the country (World Bank, 2014, TIQN, 2019). Corruption is considered as a social factor that greatly influences the behaviour of taxpayers, as individuals tend to be affected by the behaviour of others around them (Obaid et al., 2020a).

According to Dbwan (2014), the Yemeni government has not been able to combat corruption among public officials and it is becoming rampant in various sectors in the country. Dbwan further argued that corruption in the Yemeni government is considered as the main reason for tax noncompliance behaviour and several other economic impediments that are crippling the country's prosperity. Corruption among government officials is very pervasive and poses huge challenges to the Yemeni economy and has become the cornerstone to the noncompliance behaviour of taxpayers in the country (Al-Ttaffi \& Abdul-Jabbar, 2016; MPIC, 2018). This situation has been compounded by the inadequate efforts being taken by the relevant authorities to curb corrupt practices and address the problem effectively.

Despite the huge adverse effects of corruption on tax noncompliance, no study has investigated the influence of corruption on tax noncompliance in Yemen. This is because the corruption issue is a very sensitive issue to be investigated in the Yemeni society, where individuals and political regimes are very much against such studies (Sarker, 2014). Although the Yemeni tax authority has taken several measures to control the fragilities in the tax system, yet the issues of corruption and tax noncompliance remain persistent among individual taxpayers (Aljamaree \& Algaylee, 2007; United Nations Development Programme [UNDP], 2005; MPIC, 2018; TIQN, 2019; Obaid et al., 2020a). Therefore, the objective of the current study is to assess the effect of corruption on individual taxpayers' in Yemen and its relationship with other variables of tax noncompliance. Specifically, this study incorporates perception of corruption in the Yemeni government in the tax noncompliance model as a new variable, which has not been investigated before in the Yemeni context. Further, the study investigates if a relationship exists between tax rate, penalty rate and, income and education levels and tax noncompliance in the context of Yemen.

\section{Literature Review}

Several studies have been conducted in both developing and developed nations around the world regarding the issues of tax noncompliance. However, there is no universal standard to define tax noncompliance due to differences in scope and factors that drive taxpayers toward noncompliance behaviour (Yusof et al., 2014; Obaid et al., 2020a). Different authors have different perspectives in defining tax noncompliance behaviour. Tax noncompliance occurs through failure to file tax returns, misreporting income or misreporting allowable subtractions from taxable income or tax due. Khan and Ahmad (2014) stated that noncompliance is a process by which a taxpayer is not willing to file, report and pay his or her tax to the tax authority. Thus, tax noncompliance refers to any difference between the actual amount of taxes paid and the amount of taxes due (Kamleitner, Korunka, \& Kirchler, 2012).

Some researchers are of the view that noncompliance can manifest itself in a variety of forms that include, the failure to present tax returns within the specified time; not submitting at all; understating the income; overstating deductions; and not paying the assessed taxes on or before the due date (Al-Ttaffi \& Abdul-Jabbar, 2015; James \& Alley, 2002; Alabede, et al., 2011; Al-Ttaffi, 2017; Alkhatib et al., 2019; Chohan, 2020). Tax noncompliance can be either intentional and unintentional failure of taxpayers to fulfil their tax obligations (James \& Alley, 2002). Intentional noncompliance is when the taxpayer deliberately takes advantage of the tax rules and regulations for his/her own gain; whereas unintentional noncompliance could be due to lack of awareness or knowledge or due to the common mistakes encountered in the process of applying the tax law (Alabede et al., 2011; Kirchler, 2007). This makes the issue of noncompliance very worrisome, especially to developing countries, such as Yemen, where the tax laws and enforcement agencies are weak. Hence, the government is deprived of substantial tax income that would have been useful for nation building.

\subsection{Corruption}

Corruption remains a complex political, social, as well as economic phenomenon confronting and bedeviling every country in various capacities (Rohwer, 2009). Corruption is a concept that indicates an abuse of power for personal favour or gain (Aguilera \& Vadera, 2008). Alm et al. (2016) stated that the relationship between corruption and tax noncompliance has existed for long, and both aspects pose a substantial threat to world economies. Corrupt practices appear to dramatically reduce government taxation efficiency, as any taxpayer could easily evade taxes by bribing tax officials, rather than paying full taxes (Alkhatib et al., 2019). Akdede (2011) maintained that the extent of 
corruption amongst tax officials leads to escalations in the level of tax noncompliance among taxpayers. Okpala (2013) studied the factors that lead to tax evasion and avoidance in Nigeria and found that the level of corruption among the tax officials has a positively significant association with tax evasion. It has also been argued that increasing corruption levels will lead to higher rate of tax noncompliance (Alm et al., 2016).

Other researchers have also indicated that corruption positively relates to tax noncompliance (Mansor \& Gurama, 2016). Many studies have found that taxpayers are more sceptical about corrupt practices of public officials, and this is their main reason for not complying with the tax authorities and reporting their taxes (John \& Slemrod, 2008; Nor Ghani et al. 2012; Alm et al., 2016). Taxpayers are of the opinion that the high level of corruption among the tax personnel and the inefficient tax system and administration, could encourage both individual as well as corporate level taxpayers, to hide their income, thus falling into the trap of tax noncompliance behaviour (Wadhwa \& Pal, 2012).

In addition, individual taxpayers are of the view that the high level of corruption among the tax personnel and a corrupt tax system and administration, encourage them to hide their income, thus driving them toward tax noncompliance (Rosid et al., 2018; Augustine \& Enyi, 2020; Imam \& Jacobs, 2007; Gupta, 2008; Cerqueti \& Coppier, 2009; Akdede, 2011; Akinyomi \& Okpala, 2013; Alon \& Hageman, 2013; Gurama, 2015). Further, Tijani and Mathias (2013) discovered a positive relationship between corruption and tax noncompliance. They concluded that corruption contributes and motivates taxpayers towards tax noncompliance behaviour. Consequently, this study hypothesizes the following:

$\mathrm{H}_{1}$ : There is a positive relationship between corruption and tax noncompliance.

\subsection{Tax Rate}

Tax rate denotes the quantum of tax that a taxpayer pays in accordance with the taxable items and tax laws. Several studies in both developed and across developing countries have been undertaken in the domain of tax noncompliance and tax rate, and the findings show there is positive relationship (Guldana, 2013; Freire-Serén \& Panadés, 2013; Cebula, 2013; Abiola \& Asiweh, 2012; Mughal \& Akram, 2012; Muhrtala \& Ogundeji, 2013; Gurama, 2015; Ayuba et al., 2016; Sinnasamy \& Bidin, 2017). Overall, these studies have shown that the tax rate is directly related to the taxpayers' ability to behave positively or negatively based on their opinion of tax noncompliance. Taxpayers use the high rate of taxes as an excuse to evade taxes and often under- report their taxable income to the tax authority.

Among the early studies, Allingham and Sandmo (1972) demonstrated that a higher tax rate will instigate more tax noncompliance. Spicer and Becker (1980) also found that tax rate is the factor most responsible for tax noncompliance when the respondents of the study were told that their tax rate is higher than any normal taxpayer. McGee and Rossi (2006) confirmed that tax rate positively influences tax evasion. What this indicates is that, "there is a relationship between the tax rate and tax noncompliance". Many studies, such as Tijani and Mathias (2014); Mansor and Gurama (2016); Teng and Manual (2016); and Sinnasamy \& Bidin (2017), have also found that high tax rate is positively associated with tax noncompliance behaviour among individual taxpayers.

On the other hand, some studies have confirmed that tax noncompliance is low when the study respondents were told that their tax rate is the lowest among other categories of taxpayers (Olowookare \& Fasina, 2013; Friedland et al., 1978; Clotfelter, 1983). Others have found a negative relationship between tax rate and tax noncompliance (Nzaro et al., 2013; Ibadin \& Eiya, 2013; Ottone et al., 2018). Therefore, we hypothesize the following:

$\mathrm{H}_{2}$ : There is a positive relationship between tax rate and tax noncompliance.

\subsection{Penalty Rate}

Penalty rate is an additional charge imposed on taxpayers who are guilty of noncompliance behaviour in terms of the tax laws as well as by the tax authority. It is a deterrence policy by the tax authority to discourage taxpayers from noncompliance and encourage them to comply voluntarily (Mansor \& Gurama, 2016). Several studies have found that the noncompliance of taxpayers is linked to tax penalty. Doran (2009) ascertained that penalties serves as a motivator for taxpayers to fulfil or obey tax laws, particularly when they consider the penalties to be greater than the cost of noncompliance. Oladipup and Obazee (2016) established the existence of a significant and positive relationship between tax penalties and compliance. Castro and Scartascini (2015) maintained that increasing the severity of penalties could discourage tax noncompliance and encourage compliance.

It is also believed that higher penalties will lead to tax noncompliance because the penalty rate is a mechanism imposed to discourage taxpayers from noncompliance behaviour (Cherry, 2001). From another perspective, taxpayers are expected to adhere to tax laws when the rate of penalty is high, as they fear the consequences of being 
detected and punished and be viewed negatively by their peers. Early researchers, such as Allingham and Sandmo (1972), and the later researchers, such as Oladipup and Obazee (2016), have argued that a higher penalty rate will lead to lower tax noncompliance behaviour.

However, Crane and Nourzad (1990) found that there is a negative relationship between tax penalty rate and noncompliance, whereas others have found that there is no significant relationship between penalty rate and tax noncompliance (Pommerehne \& Wech-Hannemann, 1996; Al-Ttaffi, 2009; Kuria et al., 2013). Further, Twum (2014) contended that there is a negative relationship between tax penalty rate and tax noncompliance behaviour. Going by these mixed findings and inconsistencies in the association between penalty rate and tax noncompliance behaviour in previous studies, in this study, we hypothesize that:

$\mathrm{H}_{3}$ : There is a negative relationship between penalty rate and tax noncompliance.

\subsection{Income Level}

Income level of taxpayers is the main criteria by which taxpayers are taxed (Mansor \& Gurama, 2016). In order to determine income level, tax authorities around the world use different methods to impose and collect such taxes on behalf of the government. Accordingly, income tax is imposed on taxpayers based on the prevailing tax laws and in proportion to individual earnings. Studies on taxpayers' income level have revealed different findings. John and Slemrod (2007) argued that taxpayers with a low income have the highest possibility of evading taxes. According to them, in many instances, underreported taxes involve low income earners. Similarly, Nor Ghani et al. (2012); Malkawi and Haloush (2008); Devos (2006); and Nor Aziah et al. (2011), found that taxpayers' income category has a positive association with tax noncompliance. They concluded that high income earned through misconduct and fraudulent sources encourage underreporting and increase noncompliance behaviour.

Other studies have found mixed results, where some have found a negative association between income level and tax noncompliance. Al-Ttaffi (2009) and Alm et al. (1992) found that income level is negatively related to tax noncompliance behaviour. Alm et al. (1992) further argued that taxpayers with high income have a higher likelihood to comply with paying their taxes compared to low income earners. In other words, taxpayers' income is a significant factor that determines compliance behaviour of individual taxpayers. This also implies that there is a negative relationship between income level and tax noncompliance. High income earners, on the other hand, are less likely to evade tax, compared to those with low income, i.e., those earning high income have a high rate of reporting their due taxes. Thus, this study hypothesizes that:

$\mathrm{H}_{4}$ : There is a negative relationship between income level and tax noncompliance.

\subsection{Education Level}

Taxpayers' education level is considered as a determinant of tax compliance as indicated by previous studies. Richardson (2006) stated that education can lead to greater awareness among taxpayers about all the procedures of taxation and the reasons why taxes should be paid. Taxpayers' education level, in terms of their being knowledgeable and aware of the tax laws, the reasons for paying taxes, the procedures for assessing and reporting taxes, and the benefits of paying taxes, would lead to higher tax compliance among such taxpayers. Prior studies, such as Jackson and Milliron (1986), have contended that education level has to do with the ability of a taxpayer to understand whether to comply or not comply with the tax laws. A mixed finding has also been reported in some of the previous studies.

Various studies on the education level of taxpayers has established that education has a strong (positive relationship) effect on increasing the awareness of taxpayers' as well as tax compliance behaviour (Kayaoglu \& Williams, 2020; Mansor \& Gurama, 2016; Kasipillai et al., 2000; McGee \& Bose, 2007; Al-Ttafi, 2009; Palil \& Mustapha, 2011; Palil, Akir, \& Ahmad, 2013). On the other hand, some studies have indicated that the higher the level of education of taxpayers, the lower the anticipated rate of compliance (Ross \& McGee, 2011; Yalama \& Gumus, 2013). This means that a negative relationship exists between compliance behaviour and taxpayers' education level. In addition, Richardson (2006) reported a negative relationship between educational level and tax noncompliance. Similarly, Eriksen and Fallan (1996) established a negative relationship between education level and tax noncompliance. Based on these findings that there is a negative relationship between education level and tax noncompliance, the fifth hypothesis of this study is:

$\mathrm{H}_{5}$ : There is a negative relationship between education level and tax noncompliance.

Therefore, from the above discussed literature based on the variables of interest, this study investigates the effects of the variables on tax noncompliance among the individual taxpayers in Yemen. By achieving this objective, this study 
contributes to the literature on tax compliance and brings in a new perception of the effect of corruption, tax rate, penalty rate, and education and income levels on tax noncompliance behaviour. This will be the first study of its kind in Yemen towards the understanding of tax noncompliance behaviour.

\section{Research Methodology}

The study adopted the survey research design. A questionnaire with a five-point Likert-scale measurement, with " $1=$ strongly disagree (SD), 2=disagree (D), 3=neutral (N), 4=agree (A), and 5=strongly agree (SA)", was used for retrieving data of 400 sampled individual taxpayers in the Hadhramout Governorate, Yemen. Of the total number of questionnaires administered, only 264, representing 66\%, were correctly completed, retrieved, and used for the analysis. The collected data was analyzed using the Statistical Package for Social Sciences (SPSS) version 25. In addition, a reliability test, descriptive statistics, and multicollinearity test were performed. Multiple regression technique was also used for analyzing the data for establishing the relationship between the dependent and its predictor variables. The model employed in this research is as follows:

Tax noncompliance $=($ Constant $) \beta 0+\beta 1$ corruption $+\beta 2$ rate $+\beta 3$ penalty $+\beta 4$ income $+\beta 5$ education $+\varepsilon$

Where, corruption $=$ Corruption, rate $=$ Tax rate, penalty $=$ Penalty rate, income $=$ Income level, education=Education level, $\beta 0=$ constant in the model, $\beta 1, \beta 2, \beta 3, \beta 4, \beta 5=$ respective coefficients of the variables in the model, $\varepsilon=$ error term or omitted variables not tested in this research.

\section{Result}

The findings for the reliability test, descriptive statistics, and multicollinearity test are presented in this section. Table 1 provides the reliability test results. Zikmund, Babin, Carr, and Griffin (2013) argued that reliability values are valid when the "Cronbach's alpha coefficients fall between 0.60 and 1.0". In this case, the result in Table 1 shows that Cronbach's alpha for Corruption, Tax rate, Penalty rate, and tax noncompliance are 0.892, 0.889, 0.836, and 0.787, respectively. This indicates that the statements used for the development of the questionnaire demonstrate consistency and reliability in capturing the required information about the variables under investigation.

Table 1. Reliability test

\begin{tabular}{lcc}
\hline Variables & No. of items & Cronbach's Alpha \\
\hline Corruption & 5 & 0.892 \\
\hline Tax rate & 5 & 0.889 \\
\hline Penalty rate & 4 & 0.836 \\
\hline Tax noncompliance & 3 & 0.787 \\
\hline
\end{tabular}

Table 2 illustrates the descriptive statistics analysis. The findings show that Corruption has a mean of 3.54, and standard deviation of 0.965 ; the mean value of tax rate is 3.82 while the standard deviation is 0.798 ; Penalty rate has a mean of 3.87 with standard deviation of 0.792 ; the mean of income level is 3.69 and the standard deviation is 0.803 ; education level has a mean of 3.77 with standard deviation of 0.789 ; and finally, tax noncompliance has a mean value of 3.52 .

Table 2. Descriptive statistics

\begin{tabular}{llll}
\hline Variables & $\mathrm{n}$ & Mean & Standard Deviation \\
\hline Corruption & 264 & 3.54 & 0.965 \\
\hline Tax rate & 264 & 3.82 & 0.798 \\
\hline Penalty rate & 264 & 3.87 & 0.792 \\
\hline Income level & 264 & 3.69 & 0.803 \\
\hline Education level & 264 & 3.77 & 0.789 \\
\hline Tax noncompliance & 264 & 3.52 & 0.932 \\
\hline
\end{tabular}

Table 3 shows the results of the multicollinearity test. The most widely used method to conduct this analysis is by employing the variance inflation factor (VIF) for every independent variable. The result of the test indicates that the 
VIF for Corruption, Tax rate, Penalty rate, and Income and Education levels are 1.416, 3.439, 1.452, 3.028, and 1.022 , respectively. This indicates the non-violation of the multicollinearity rule in this study.

Table 3. Multicollinearity test

\begin{tabular}{lll}
\hline Variables & Tolerance & VIF \\
\hline Corruption & 0.706 & 1.416 \\
\hline Tax rate & 0.791 & 3.439 \\
\hline Penalty rate & 0.689 & 1.452 \\
\hline Income level & 0.330 & 3.028 \\
\hline Education level & 0.978 & 1.022 \\
\hline
\end{tabular}

The regression analysis result in this research is presented in Table 4. The outcome shows that Corruption, Tax rate, Penalty rate, and Education level have a positive association with tax noncompliance; however, Income Level has a negative association with tax noncompliance. The result also indicates that Corruption, Tax rate, Penalty rate, and Income level are significantly related to tax noncompliance, while Education level is not significantly related to tax noncompliance.

Table 4. Regressions analysis of coefficients

\begin{tabular}{llllll}
\hline \multirow{2}{*}{ Model } & \multicolumn{4}{l}{ Unstandardized Coefficients } & \multicolumn{3}{l}{ Standardized Coefficients } \\
\cline { 2 - 6 } & $\beta$ & Std. Error & Beta & $\mathrm{t}$ & Sig. \\
\hline 1 (Constant) & 0.252 & 0.302 & & 0.833 & 0.406 \\
\hline Corruption & 0.465 & 0.053 & 0.482 & 8.736 & $0.000^{* * *}$ \\
\hline Tax rate & 0.328 & 0.101 & 0.279 & 3.245 & $0.001^{* * *}$ \\
\hline Penalty rate & 0.192 & 0.066 & 0.163 & 2.922 & $0.004^{* * *}$ \\
\hline Income level & -0.154 & 0.075 & -0.166 & -2.056 & $0.041^{*}$ \\
\hline Education level & 0.058 & 0.041 & 0.067 & 1.429 & 0.154 \\
\hline
\end{tabular}

a. Dependent Variable: Tax noncompliance

Note: $\mathrm{R}^{2}=.446 ; \mathrm{F}=41.507 ; \mathrm{p}<0.05, * * \mathrm{p}<0.01, * * * \mathrm{p}<0.001$ (significant)

$\beta=$ Beta coefficient

\section{Discussion}

According to the findings shown in Table 4, three Hypotheses, i.e., H1, H2, and H4, are supported (i.e., the study's predictions are accepted); while Hypotheses 3 and 5 are not supported or rejected. These can be seen in Table 5, where the hypotheses statement and findings are matched. Hypotheses 3 and 5 are not supported due to the fact that the prediction of the relationship between penalty rate and education level and tax noncompliance is rejected. The findings depict that both the variables of penalty rate and education level positively influence tax noncompliance, which is contrary to our proposed hypotheses in this study.

Table 5. Hypothesis and variable findings

\begin{tabular}{lll}
\hline Hypothesis & Statement & Findings \\
\hline H1 & There is a positive relationship between corruption and tax noncompliance. & Supported \\
\hline H2 & There is a positive relationship between tax rate and tax noncompliance. & Supported \\
\hline H3 & There is a negative relationship between penalty rate and tax noncompliance. & Not Supported \\
\hline H4 & There is a negative relationship between income level and tax noncompliance. & Supported \\
\hline H5 & There is a negative relationship between education level and tax noncompliance. & Not Supported \\
\hline
\end{tabular}


In studying the Hadhramout Governorate, the findings show that penalty rate has a positive relationship with tax noncompliance. This shows that Yemini taxpayers view that high penalty rate is meaningless without effective and efficient enforcement of the penalty by the relevant authority. In other words, even if a country has a high penalty for noncompliant taxpayers, poor or weak enforcement of laws relating to taxes and penalty on tax defaulters will remain a hindrance to achieving increased tax compliance rate. This could also impact on the integrity and performance of the tax authority and the government from the viewpoint of taxpayers. Further, it will encourage more tax noncompliance behaviour among the taxpayers. In line with these findings, Doran (2009) and Oladipupo and Obazee (2016) argued that when the tax authority lacks the capability to enforce the tax laws and penalty for tax noncompliance, taxpayers would not value the importance of reporting their income and due taxes and this will make tax noncompliance behaviour more rampant.

The result of this research also indicates contrary finding for Hypothesis 5, as the taxpayers' education level shows a negative link with tax noncompliance. Many studies have indicated that adequate knowledge of tax laws, assessment, and reporting process, could lead to greater awareness of tax policies, and hence, enhance tax compliance among taxpayers (Purwanto \& Indrawan, 2020; Devos, 2006; Aziah et al., 2011). This has been attributed to the fact that normally, the education level of individuals can positively influence the attitude and behaviour of a person in most circumstances. But contrary to this, our finding indicates that a positive relationship exists between education level and tax noncompliance behaviour among individual taxpayers. This means that the more the individual taxpayer is knowledgeable about the tax related laws and processes, the more he or she can manipulate and interpret the laws and policies to his or her own advantage, and then, engage in noncompliance behaviour. This is obvious as often, people use the loopholes in the tax laws and weaknesses in the tax process to lower their tax and maximize their noncompliance by exploiting the economic and other environmental factors to their own benefit (Smith and Kinsley, 1987).

\section{Conclusion, Limitations, and Future Research}

From the evidence emanating from the current study that investigated the relationship between corruption and other tax noncompliance variables and tax noncompliance behaviour in the Hadhramout Governorate in Yemen, the study finds that: (i) Corruption positively and significantly influences tax noncompliance; (ii) Tax rate positively and significantly influences tax noncompliance; (iii) Penalty rate positively and significantly influences tax noncompliance; (iv) Income level has a negatively significant relationship with tax noncompliance; and (v) Education level is positively and significantly related to tax noncompliance.

Tax noncompliance mainly results in loss of revenue needed by the government for public activities. This will adversely affect the performance of the public sector in a country, and hence, cripple the government's ability to provide for the social well-being of its citizens. In addition, it will incapacitate the competency and developmental programs of a nation collectively. This research explores the factors that influence tax noncompliance in the Hadhramout Governorate, Yemen. The results of the study are very important to academic researchers as well as students in the area of taxation, especially in Yemen and other developing nations that have similar characteristics. To scholars, the current findings add new evidence from a third world country regarding factors that influence tax noncompliance, particularly the role of corruption among government and tax officials, which has been a gap in the context of Yemen. The findings help in the better understanding of the factors that encourage tax noncompliance behaviour among individual taxpayers from the Arabian region. To the students in the area of taxation, this study adds new information on and insights into the factors tested in this study and their relationship with tax noncompliance behaviour.

Further, the current results clearly describe the association between the factors that the study investigated. It is evident that tax noncompliance erodes and decreases revenues accrued from taxes which are very essential for supporting public expenditure. It is also crucial to highlight that individual taxpayers are mentally and rationally often willing to abide by tax laws and the requirements of the authority. However, other factors may also influence them, making them develop a negative attitude toward tax compliance. In addition to highlighting a clearer comprehension of the factors impacting tax noncompliance, the study has practical implications for the tax authority as well as the government on how to curb the phenomenon by enacting new policies and enforcing tax laws more stringently. The findings are equally beneficial to tax practitioners in Yemen and other tax administration stakeholders, at large.

This study has some limitations. Firstly, the sample used in this study considers only individual taxpayers over other categories of taxpayers. Additionally, the current study's scope is only the Hadhramout Governorate taxpayers, representing one governorate of the 21 governorates in Yemen. This makes it not feasible to generalize the results of 
the study due to differences in geographical location and perceived factors that lead to tax noncompliance. Therefore, future studies should consider employing a larger sample and other categories of taxpayers, such as small and medium enterprises. The scope of future studies should consider other regions and governorates in the country.

Further, the technique of sampling as well as data collection method employed by the study are two other limitations. The data and information collected from the survey are not adequately rich to explain the tax noncompliance phenomenon in the Hadhramout Governorate. Thus, future researchers can give a thought to alternative data retrieval approaches, like the mixed method. Finally, the current study investigated five factors as determinants of tax noncompliance. It is recommended that future studies look into other factors in addition to those factors influencing tax noncompliance behaviour already examined, thus potentially covering a greater scope, which has yet to be considered or included here but which may have conflicting results. Moreover, future studies should consider including mediating variables to investigate their influence on the relationship between the existing determinants of tax noncompliance behaviour in Yemen.

\section{Acknowledgements}

Deepest appreciation goes to the Department of Accounting, Faculty of Administrative Sciences, Seiyun University, Hadhramout, Yemen, for providing the scholarship to one of the authors to undertake this study. Sincere appreciation also attributed to the Tunku Puteri Intan Safinaz, School of Accountancy, Universiti Utara Malaysia, Malaysia.

\section{References}

Abiola, J., \& Asiweh, M. (2012). Impact of tax administration on government revenue in a developing economy-a case study of Nigeria. International Journal of Business and Social Science, 3(8), 99-113.

Aguilera, R. V., \& Vadera, A. K. (2008). The dark side of authority: Antecedents, mechanisms, and outcomes of organizational corruption. Journal of Business Ethics, 77(4), 431-449. https://doi.org/10.1007/s10551-007-9358-8

Akdede, S. H. (2011). Corruption and tax evasion. Doğuş Üniversitesi Dergisi, 7(2), 141- 149.

Al-Fasel, T (2014). Low tax revenue contribution in GDP. Al-Thawrah. Net. Retrieved September 14, 2016, from http://www.althawranews.net/archives/95622

Al-Jaaidi, K. S., Manaf, N. A. A., \& Karlinsky, S. S. (2011). Tax evasion as a crime: A survey of perception in Yemen. International Journal of Business and Management, 6(9), 190-201. https://doi.org/10.5539/ijbm.v6n9p190

Al-Jamaree, Y., \& Algaylee, A. (2007). Financial ministry implements transparency principle to reform the financial regulations and laws. Sabanews. Net. Retrieved June 10, 2016, from http://www.sabanews.net/ar/news131480.htm

Alkhatib, A. A., Abdul-Jabbar, H., Abuamria, F., \& Rahhal, A. (2019). The effects of social influence factors on income tax evasion among the palestinian SMEs. International Journal of Advanced Science and Technology, 28(17), 690-700.

Allingham, M., \& Sandmo, A. (1972). Income tax evasion: A theoretical analysis. Journal of Public Economics, 1(3-4), 323-338. https://doi.org/10.1016/0047-2727(72)90010-2

Alm, J. (2012). Measuring, explaining, and controlling tax evasion: lessons from theory, experiments, and field studies. International Tax Public Finance, 1(9), 54-77. https://doi.org/10.1007/s10797-011-9171-2

Alm, J., Martinez-Vazquez, J., \& McClellan, C. (2016). Corruption and firm tax evasion. Journal of Economic Behavior \& Organization, 124(1), 146-163. https://doi.org/10.1016/j.jebo.2015.10.006

Alon, A., \& Hageman, A. M. (2013). The impact of corruption on firm tax compliance in transition economies: Whom do you trust?. Journal of Business Ethics, 116(3), 479-494. https://doi.org/10.1007/s10551-012-1457-5

Al-Saadi, M. S. (2014). Interview with the minister of planning and international cooperation. Al-Thawra Official Journal.

Al-Sharabi, \& Al-Slehi. (2015). Taxes bitter harvest basket. Alrai Press.Net, Retrieved February 10, 2017, from http://www.alraipress.com/news4194.html

Al-Ttaffi, L. (2009). Determinants of tax evasion: An empirical evidence from the Republic of Yemen. Unpublished Master Dissertation, Universiti Utara Malaysia.

Al-Ttaffi, L. (2017). Determinants of tax non-compliance behaviour of Yemeni SMEs: A moderating role of Islamic religious perspective. Unpublished doctoral thesis, Universiti Utara Malaysia. 
Al-Ttaffi, L., \& Abdul-Jabbar, H. (2015, August). Does Muslim view on tax influence compliance behaviour?. International Conference on Accounting Studies (ICAS). Johor Bahru, Johor, Malaysia.

Al-Ttaffi, L., \& Abdul-Jabbar, H. (2016, October 5-6). Geopolitics and its implications for tax administration. International Conference on Government and Public Affair (ICOGPA), Sintok, Malaysia. School of Government, Universiti Utara Malaysia.

Augustine, A. A., \& Enyi, E. P. (2020). Control of corruption, trust in government, and voluntary tax compliance in South-West, Nigeria. Management, 8(1), 84-97.

Ayuba, A., Saad, N., \& Ariffin, Z, Z. (2020). Perceived service orientation, economic factors, psychological factors and tax compliance: Evidence from Nigerian SMEs. Malaysian Management Journal, 12(20), 41-57.

Aziah, A. M. N., Stewart, S. K., \& Khaled, S. Y. (2011). Taxation as a crime: A survey of perception in Yemen. International Journal of Business and Management, 6(9), 190. https://doi.org/10.5539/ijbm.v6n9p190

Becker, G. S. (1968). Crime and punishment: An economic approach. Journal of Political Economy, 76(2), 169-217. https://doi.org/10.1086/259394

Castro, L., \& Scartascini, C. (2015). Tax compliance and enforcement in the pampas evidence from a field experiment. Journal of Economic Behavior \& Organization, 116, 65-82. https://doi.org/10.1016/j.jebo.2015.04.002

Cebula, R. J. (2013). New and current evidence on determinants of aggregate federal personal income tax evasion in the United States. American Journal of Economics and Sociology, 72(3), 701-731. https://doi.org/10.1111/ajes.12020

Central Organization of Audit \& Control COAC. (2012). Annual report. Official Supervisory Authority. Sana'a.

Central Organization of Audit \&Control COAC. (2014). Annual report. Official Supervisory Authority. Sana'a.

Central Organization of Control \& Audit COCA. (2018). Discuss the report of the Central Organ on the results of the review and evaluation of tax procedures. Saba Net. Retrieved from https://www.sabanews.net/ar/news514514.htm

Cerqueti, R., \& Coppier, R. (2009). Tax revenues, fiscal corruption and shame costs. Economic Modelling, 26(6), 1239-1244. https://doi.org/10.1016/j.econmod.2009.06.005

Cherry, T. L. (2001). Financial penalties as an alternative criminal sanction: Evidence from panel data. Atlantic Economic Journal, 29(4), 450-458. https://doi.org/10.1007/BF02299333

Chohan, U. W. (2020). Tax Evasion \& Whistleblowers: Curious Policy or Durable Strategy?. CASS Working Papers on Economics \& National Affairs. http://doi.org/10.2139/ssrn.3529340

Clotfelter, C. T. (1983). Tax evasion and tax rates: An analysis of individual returns. The Review of Economics and Statistics, 363-373. https://doi.org/10.2307/1924181

Crane, S. E., \& Nourzad, F. (1990). Tax rates and tax evasion: evidence from California amnesty data. National Tax Journal, 189-199.

Dbwan, A. (2014). Fighting the Culture of Corruption in Yemen. The World Bank.

Devos, K. (2006). The attitude of australian and new zealand tertiary student towards tax evasion: A comparative study and demographic analysis. New Zealand Journal of Taxation Law and Policy, 12(4), 293-323.

Doran, M. (2009) Tax penalties and tax compliance: A personal income tax non-compliance in Malaysia. PhD Thesis, Victoria University, Melbourne. Harvard Journal on Legislation, 46(1).

Eriksen, K., \& Fallan, L. (1996). Tax knowledge and attitudes towards taxation; A report on a quasi-experiment. Journal of Economic Psychology, 17(3), 387-402. https://doi.org/10.1016/0167-4870(96)00015-3

Freire-Serén, M. J., \& Panadés, J. (2013). Do higher tax rates encourage/discourage tax compliance? Modern Economy. https://doi.org/10.4236/me.2013.412086

Friedland, N., Maital, S., \& Rutenberg, A. (1978). A simulation study of income tax evasion. Journal of Public Economics, 10(1), 107-116. https://doi.org/10.1016/0047-2727(78)90008-7

Guldana, B. K. (2013). Tax evasion: Criminological characteristic, problems of criminal liability application and improvement of the mechanism of crime suppression. Middle East Journal of Scientific Research, 16(7), 907-912. 
Gupta, R. (2008). Tax evasion and financial repression. Journal of Economics and Business, 60(6), 517-535. https://doi.org/10.1016/j.jeconbus.2007.10.002

Gupta, R., \& McGee, R. (2009). An empirical study of demographics of perception of tax evasion in New Zealand. New Zealand Journal of Taxation Law and Policy, 65(12), 1-40.

Gurama, Z. (2015). Tax Evasion Determinants: Evidence from Nigeria. Unpublished Master Dissertation, Universiti Utara Malaysia.

Hindriks, J., Peralta, S., \& Weber, S. (2008). Competing in taxes and investment under fiscal equalization. Journal of Public Economics, 92(12), 2392-2402. https://doi.org/10.1016/j.jpubeco.2007.11.012

Ibadin, P. O., \& Eiya, O. F. I. A. F. O. H. (2013). Tax evasion and avoidance behaviour of the self-employed Nigerians. European Journal of Business and Management, 5(6), 1-16.

Imam, P. A., \& Jacobs, D. F. (2007). Effect of corruption on tax revenues in the Middle East (No. 2007-2270). International Monetary Fund.

Index Mundi. (2019) Yemen Economy Profile 2019. Annual Report. Retrieved December 14, 2019, from https://www.indexmundi.com/yemen/economy_profile.html

International Monetary Fund (IMF). (2016). Press release and statement by the executive. IMF Country Report Yemen.

Jackson, B. R., \& Milliron, V. C. (1986). Tax compliance research: Findings, problems and prospects. Journal of Accounting Literature, 5, 125-165.

James, S., \& Alley, C. (2002). Tax compliance, self-assessment and tax administration. Journal of Finance and Management in Public Services, 2(2), 27-42.

Johns, A., \& Slemrod, J. (2008). The distribution of income tax non-compliance. Retrived From http://www.bus.umich.edu/otpr/DITN\%20091308.pdf

Kamleitner, B., Korunka, C., \& Kirchler, E. (2012). Tax compliance of small business owners: A review. International Journal of Entrepreneurial Behavior \& Research, 18(3), 330-351. https://doi.org/10.1108/13552551211227710

Kasipillai, J., Baldry, J., \& Rao, D. S. P. (2000). Estimating the size and determinants of hidden income and tax evasion in Malaysia. Asian Review of Accounting, 8(2), 25-41. https://doi.org/10.1108/eb060727

Kayaoglu, A., \& Williams, C. C. (2020). Explaining Tax Non-Compliance from a Neo-Institutionalist Perspective: Some Lessons from a Public Opinion Survey in Turkey. Sosyoekonomi, 28(43), 89-105. https://doi.org/10.17233/sosyoekonomi.2020.01.05

Khan, W. A., \& Ahmad, P. F. (2014). Causes of tax evasion in Pakistan: A case study on southern Punjab. International Journal of Accounting and Financial Reporting, 4(2), 273-294. https://doi.org/10.5296/ijafr.v4i2.6484

Kirchler, E. (2007). The economic psychology of tax behaviour. Cambridge: Cambridge University Press. https://doi.org/10.1017/CBO9780511628238

Kuria, K., Ngumi, P., \& Rugami, J. (2013). Factors affecting rental income tax compliance among landlords in Kilifi municipality in Kenya. Journal of Business Administration and Management (BAM), 3(5), 997-1008.

Malkawi, B. H., \& Haloush, H. A. (2008). The case of income tax evasion in Jordan: symptoms and solutions. Journal of Financial Crime, 15(3), 282-294. https://doi.org/10.1108/13590790810882874

Mansor, M., \& Gurama, Z. (2016). The determinants of tax evasion in Gombe State Nigeria. International Journal of Economics and Financial Issues, 6(S7) 165-170. https://doi.org/10.15405/epsbs.2016.08.14

McGee, R. W., \& Lingle, C. (2006). Tax evasion and business ethics: A comparative study of Guatemala and the USA. https://doi.org/10.2139/ssrn.892323

McGee, R. W., \& Rossi, M. J. (2006). The ethics of tax evasion: A survey of law and business students in Argentina. https://doi.org/10.2139/ssrn.875892

McGee, R., \& Bose, S. (2007). The ethics of tax evasion: A comparative study of Australian, New Zealand \& the U.S.A opinions. Andreas School of Business. Working Paper. https://doi.org/10.2139/ssrn.979408

Ministry of Planning \& International Cooperation (MPIC). (2018). Annual Report. Retrieved February 1, 2010, from 
http://www.mpic-yemen.org

Mughal, M. M., \& Akram, M. (2012). Reasons of tax avoidance and tax evasion: Reflections from Pakistan. Journal of Economic and Behavioral Studies, 4. https://doi.org/10.22610/jebs.v4i4.320

Muhrtala, T. O., \& Ogundeji, M. (2013). Professionals' perspective of tax evasion: Some evidence from Nigeria. Universal Journal of Accounting and Finance, 1(2), 35-41.

Nor Aziah, A. M., Stewart, S. K., \& Khaled, S. Y. A. (2011). Taxation as a crime: A survey of perception in Yemen. International Journal of Business andMangement, 6(9). https://doi.org/10.5539/ijbm.v6n9p190

Nor Ghani, Md., Nor Mansor, J., Mohd, A. S. Z., \& Razieh, T. (2012). Estimating factors affecting tax evasion in Malaysia: A neural network method analysis. Prosiding PERKEM VII, JILID 2, 1524-1535.

Obaid, M. M., Ibrahim, I., \& Mat-Udin, N. (2020a). An investigation of the determinants of tax compliance among Yemeni manufacturing SMEs using the Fisher model. International Journal of Psychosocial Rehabilitation, 24(4), 1809-1824. https://doi.org/10.37200/IJPR/V24I4/PR201289

Obaid, M. M., Ibrahim, I., \& Mat-Udin, N. (2020b). Determinants of SMEs tax compliance in Yemen: A Pilot investigation. IOSR Journal of Humanities and Social Science, 25(1), 64-75. https://doi.org/10.9790/0837-2501016475

Okpala, K. E. (2013). Appraisal of factors influencing tax avoidance and evasion in Nigeria. International Journal of Research in Commerce and Management, 4(5), 107-111.

Oladipupo, A. O., \& Obazee, U. (2016). Tax knowledge, penalties and tax compliance in small and medium scale enterprises in Nigeria. iBusiness, 8(1), 1. https://doi.org/10.4236/ib.2016.81001

Olowookere, J. K., \& Fasina, H. T. (2013). Taxpayers' education: A key strategy in achieving voluntary compliance in Lagos State, Nigeria. European Journal of Business and Management, 5(10), 146-154.

Ottone, S., Ponzano, F., \& Andrighetto, G. (2018). Tax compliance under different institutional settings in Italy and Sweden: an experimental analysis. Economia Politica, 35(2), 367-402. https://doi.org/10.1007/s40888-018-0093-7

Palil, M. R., \& Mustapha, A. F. (2011). Factors affecting tax compliance behaviour in self-assessment system. African Journal of Business Management, 5(33), 12864. https://doi.org/10.5897/AJBM11.1742

Palil, M. R., Akir, M. R., \& Ahmad, W. F. B. A. (2013). The perception of taxpayers on tax knowledge and tax education with level of tax compliance: A study the influences of religiosity. ASEAN Journal of Economics, Management and Accounting, 1(1), 118-129.

Pommerehne, W. W., \& Weck-Hannemann, H. (1996). Tax rates, tax administration and income tax evasion in Switzerland. Public Choice, 88(1-2), 161-170. https://doi.org/10.1007/BF00130416

Purwanto, P., \& Indrawan, R. (2020). The determinants of tax evasion in directorate general of customs and excise Jakarta. In Annual International Conference on Accounting Research 187-190. https://doi.org/10.2991/aebmr.k.200309.041

Richardson, G. (2006). Determinants of tax evasion: A cross-country investigation. Journal of International Accounting, Auditing and Taxation, 15(2), 150-169. https://doi.org/10.1016/j.intaccaudtax.2006.08.005

Rohwer, A. (2009). Measuring corruption: A comparison between the transparency international's corruption perceptions index and the world bank's worldwide governance indicators. CESifo DICE Report, 7(3), 42-52.

Rosid, A., Evans, C., \& Tran-Nam, B. (2018). Tax Non-Compliance and Perceptions of Corruption: Policy Implications for Developing Countries. Bulletin of Indonesian Economic Studies, 54(1), 25-60. https://doi.org/10.1080/00074918.2017.1364349

Ross, A. M., \& McGee, R. W. (2011). A six-country study on education level and ethical attitude toward tax evasion. In Academy of Educational Leadership, 1(6), 1-63.

Sarker, N. M. (2014). Arab spring and the contemporary geopolitics of the Middle East. Peace and Security Review, $6(12), 39-62$.

Sinnasamy, P., \& Bidin, Z. (2017). The relationship between tax rate, penalty rate, tax fairness and excise duty non-compliance. In SHS Web of Conferences, (3), 1-7. https://doi.org/10.1051/shsconf/20173411001

Smith, K. W., \& Kinsley, K. A. (1987). Understanding taxpayer's behavior: A conceptual framework with 
implication for research. Law and Society Review, 12(4), 639-663. https://doi.org/10.2307/3053599

Spicer, M. W., \& Becker, L. A. (1980). Fiscal inequity and tax evasion: An experimental approach. National Tax Journal, 33(2), 171-175.

Teng, Y. M., \& Manual, V. (2016). A study about economic factors influencing taxpayers' noncompliance behaviors in Kuala Lumpur, Malaysia. Imperial Journal of Interdisciplinary Research, 2(9).

Tijjani, O. P., \& Mathias, O. (2013). Professional perspective of tax evasion: Some evidence from Nigeria. Universal Journal of Accounting and Finance, 1(2).

Transparency International's Quarterly Newsletter (TIQN). (2019). A call to stamp out natural resource corruption. Retrieved from https://doi.org/https://www.transparency.org/news/feature/corruption_perceptio ns_index_2019

United Nations Development Program. (2005). Program on /Governance in the Arab Region.

Wadhwa, L., \& Pal, D. V. (2012). Tax evasion India. International Journal of Applied Engineering Research, 7(11).

World Bank. (2014). Fighting the culture of corruption in Yemen. Retrieved from http://blogs.worldbank.org/arabvoices/fighting-culture-corruption-yemen

World Bank. (2018). Browse by country or indicator data bank microdata data catalo. Retrieved from https://data.worldbank.org/indicator/SH.STA.DIAB.ZS?view=chart

Yalama, G. O., \& Gumus, E. (2013). Determinants of tax evasion behavior: Empirical evidence from survey data. International Business and Management, 6(2), 15-23.

Zikmund, W. G., Babin, B. J., Carr, J. C., \& Griffin, M. (2013). Business Research Methods. Cengage Learning. 